\title{
Human C-Peptide Immunoreactivity (CPR) in Blood and Urine - Evaluation of a Radioimmunoassay Method and Its Clinical Applications
}

\author{
T. Kuzuya, A. Matsuda, T. Saito and S. Yoshida \\ Department of Medicine, Jichi Medical School, Tochigi-ken, Japan
}

\begin{abstract}
Summary. A double-antibody radioimmunoassay method, using synthetic human connecting peptide as an immunizing antigen and standard, was evaluated for clinical assay of blood and urine samples. Normal fasting blood connecting peptide immunoreacivity (CPR) was $2.45 \pm 0.96 \mathrm{ng} / \mathrm{ml}$, increasing promptly after a $50 \mathrm{~g}$ oral glucose load, but somewhat slower than insulin. Molar concentration of CPR exceeded that of insulin. CPR responses to glucose were subnor$\mathrm{mal}$ in diabetics, very low in juvenile-type cases, and often poor in patients on insulin treatment. Fasting CPR levels were elevated in patients on corticosteroid treatment and with uraemia. A patient with insulin "auto-antibody" had high serum CPR. A considerable amount of CPR appeared in urine. Normal daily excretion of CPR was $1.52 \pm 0.55 \mu \mathrm{g} / \mathrm{kg}$ or $55.1 \pm$ $18.2 \mathrm{ng} / \mathrm{mg}$ creatinine. Urine CPR was very low in juvenile-type diabetics, and elevated in patients on corticosteroid treatment. The results confirm that blood and urine CPR are useful measures of the endocrine pancreatic function.
\end{abstract}

Key words: Synthetic human connecting peptide, Cpeptide immunoreactivity (CPR), urine CPR, blood $\mathrm{CPR}$, radioimmunoassay.

Since the discovery of proinsulin, it has become clear that connecting peptide (C-peptide), a by-product of insulin biosynthesis, is released from the pancreatic B-cells into blood together with insulin [1-3]. Subsequently, a radioimmunoassay of human C-peptide was developed $[4,5]$. It seems to provide two advantages for the evaluation of B-cell function: first, it can be performed in insulin-treated patients in whom the presence of insulin antibody interferes with usual in- sulin radioimmunoassay; second, it can measure only the endogenous secretion of the pancreas because of its high species specificity. Limited availability of human C-peptide preparation, however, has so far prevented the wide clinical application of C-peptide immunoassay.

A few years ago, the complete synthesis of human C-peptide was accomplished by Yanaihara et al. [6]. Using this preparation, Kaneko et al. [7] succeeded in establishing a radioimmunoassay of human C-peptide. Recently, a radioimmunoassay kit for human C-peptide has been developed in Japan with the use of the same synthetic preparation. We evaluated this kit and assayed human serum, plasma and urine samples in normal and pathological states. These results are reported in this paper.

\section{Materials and Methods}

\section{The Content of C-Peptide Radioimmunoassay Kit}

This kit is based on the double-antibody method, and supplied by Daiichi Radioisotope Laboratories (Tokyo). It consists of vials of lyophilized standard synthetic human C-peptide (50 ng), rabbit anti-human C-peptide serum $(10 \mathrm{ml}$ of 1:10000 dilution after reconstitution), ${ }^{125} \mathrm{I}$-labelled human C-peptide (about $2 \mu \mathrm{Ci}$, specific activity is about $200 \mathrm{mCi} / \mathrm{mg}$ ), and goat anti-rabbit $\gamma$-globulin serum. The synthetic human $\mathrm{C}$-peptide has the amino acid sequence possessing Arg-Arg in the N-terminal and Lys-Arg in the C-terminal in addition to the natural human C-peptide which is released upon conversion of proinsulin to insulin. Its molecular weight is about 3600 . The antiserum was produced by repeated injections of synthetic human C-peptide mixed with Freund's adjuvant to rabbits. One tyrosine residue was introduced to the 


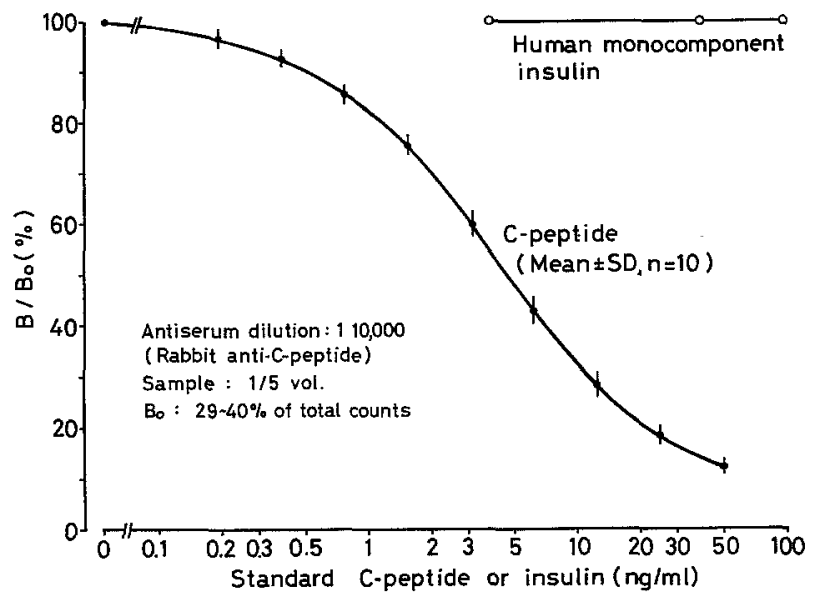

Fig. 1. The standard curve for human C-peptide radioimmunoassay. Addition of human monocomponent insulin does not affect this assay system. $B_{0}$ and $B$ represent the precipitated radioactivity without or with addition of standard C-peptide

Table 1. Assay of serum and urine samples at varying dilutions $\mathrm{s}^{\mathrm{a}}$

\begin{tabular}{lccccccccc}
\hline $\begin{array}{l}\text { A. Serum samples } \\
\text { Dilutions }\end{array}$ & \multicolumn{1}{c}{ Samples } \\
\cline { 2 - 10 } & A & B & C & D & E & F & G & H & I \\
\hline $1: 1$ & 1.1 & 2.7 & 4.8 & 6.8 & 5.2 & 6.5 & $15.0^{\mathrm{b}}$ & $15.0^{\mathrm{b}}>20^{\mathrm{b}}$ \\
$1: 2$ & 1.2 & 2.5 & 4.8 & 7.5 & 5.0 & 6.6 & $16.6^{\mathrm{b}} 16.0^{\mathrm{b}} 20^{\mathrm{b}}$ \\
$1: 4$ & & 2.1 & 4.6 & 7.5 & 5.2 & 6.8 & 18.0 & 15.2 & 24.0 \\
$1: 6$ & & & 4.3 & 7.7 & 5.5 & & & & 23.0 \\
$1: 8$ & & & 4.2 & 7.0 & 5.8 & 6.8 & 16.8 & \\
$1: 10$ & & & 5.2 & 8.4 & 5.3 & 6.8 & 16.4 & 16.5 & 23.0 \\
$1: 20$ & & & & & & & & 18.4 & 16.8 \\
\hline
\end{tabular}

B. Urine samples

Dilutions

\begin{tabular}{ccccccc}
\multicolumn{8}{c}{ Samples } \\
\hline A & B & C & D & E & F & G \\
\hline$>20^{\text {b }}$ & $>20^{\mathrm{b}}$ & $>20^{\mathrm{b}}$ & $>20^{\mathrm{b}}$ & $>20^{\mathrm{b}}$ & $>20^{\mathrm{b}}$ & $>20^{\mathrm{b}}$ \\
29 & 67 & 74 & $110^{\mathrm{b}}$ & $120^{\mathrm{b}}$ & $140^{\mathrm{b}}$ & $120^{\mathrm{b}}$ \\
27 & 66 & 68 & 92 & 130 & 160 & 134 \\
22 & 63 & 87 & 96 & 136 & 162 & 150 \\
22 & 68 & 84 & 104 & 148 & 176 & 156 \\
$19^{\mathrm{b}}$ & 73 & 90 & 105 & 150 & 155 & 155
\end{tabular}

a Corrected for $\mathrm{ng} / \mathrm{ml} \mathrm{CPR}$.

b Actual assay values were outside of the good range of standard curve.

$\mathrm{N}$-terminus of the synthetic human C-peptide to be used for the radioiodination with $\mathrm{Na}^{125} \mathrm{I} .10 \mathrm{ml}$ water or $10 \mathrm{ml} 0.1 \mathrm{M}$ phosphate buffer ( $\mathrm{pH} 7.4$ ) supplemented with $0.01 \mathrm{M}$ ethylene diamine tetraacetate (EDTA) and $0.5 \%$ bovine serum albumin (BSA) was added to each vial before use, as indicated on each vial.
The Assay Procedures of C-Peptide Immunoreactivity (CPR) and Immunoreactive Insulin (IRI)

The assay was performed in disposable plastic test tubes. $500 \mu 10.1 \mathrm{M}$ phosphate buffer containing 0.01 M EDTA and $0.5 \%$ BSA (pH 7.4), $200 \mu l$ standard C-peptide solution or test sample, $100 \mu \mathrm{l}$ anti-human $\mathrm{C}$-peptide antiserum and $100 \mu \mathrm{l}{ }^{125} \mathrm{I}$-C-peptide solution were mixed thouroughly in the test tubes. The reaction mixture was incubated at $4^{\circ} \mathrm{C}$ for 2 days, and then $100 \mu \mathrm{l}$ anti-rabbit $\gamma$-globulin serum was added, and incubated further for one day at $4^{\circ} \mathrm{C}$. Thereafter, test tubes were centrifuged at $3000 \mathrm{rpm}$ for $30 \mathrm{~min}$ in a refrigerated centrifuge. The supernatant was decanted and the remaining drop of the supernatant was removed by wiping the inside of the test tube with a rolled filter paper. The radioactivity of the precipitate was counted in a well-type automatic $\gamma$-spectrometer. All assays were performed in duplicate. Later, in order to economise with reagents and samples, the assay was performed using half the amount of each reagent and sample.

Insulin radioimmunoassay was performed in essentially the same manner [8]. Human monocomponent insulin (25.7 U/mg, Lot No. $12569 \mathrm{MC})$ donated by Novo Insulin Laboratory (Copenhagen) was used as standard. ${ }^{125} \mathrm{I}$-pork insulin (about $200 \mathrm{mCi} / \mathrm{mg}$ ) was purchased from Dainabott Laboratories (Tokyo). Anti-insulin serum was produced in a guinea pig by repeated injections of beef insulin with Freund's complete adjuvant. The second precipitating antiserum was rabbit anti-guinea pig $\gamma$-globulin serum. The reaction mixture was incubated one day each for the first and the second reactions. Borate buffer ( $\mathrm{pH} 8.5)$ containing $0.25 \%$ BSA was used for insulin assay.

\section{Sampling of Blood and Urine}

Blood was withdrawn from the arm vein fasting and during oral glucose tolerance test. Either plasma (using double oxalate containing tubes) or serum (clotting at room temperature) was prepared, and kept frozen at $-20^{\circ} \mathrm{C}$ until assay. Urine was collected, and usually kept in a refrigerator $\left(4^{\circ} \mathrm{C}\right)$, or sometimes at room temperature before an aliquot was frozen at $-20^{\circ} \mathrm{C}$ on the same day. Some urine samples were frozen immediately after voiding.

\section{Other Determinations}

Plasma glucose was determined by a glucose oxidase method using Glucostat (Worthington), or by a Technicon Auto Analyzer using neocuproine copper reagent [9]. Plasma or urine creatinine was determined according to Bosnes and Taussky [10]. 
Table 2. Effect of storage on urine CPR values

\begin{tabular}{|c|c|c|c|c|c|c|c|c|c|c|c|c|}
\hline \multirow[t]{2}{*}{ Storage conditions } & \multicolumn{12}{|c|}{ Sample } \\
\hline & A & B & $\mathrm{C}$ & $\mathrm{D}^{\mathrm{a}}$ & $\mathrm{E}^{\mathrm{a}}$ & $F^{b}$ & $\mathbf{G}$ & $\mathrm{H}$ & I & $\mathbf{J}$ & $\mathrm{K}$ & $\mathrm{L}$ \\
\hline Frozen immediately & 1.02 & 7.1 & 4.8 & 2.5 & 2.9 & 1.1 & 4.1 & 4.8 & 5.5 & 2.6 & 1.4 & 2.4 \\
\hline \multicolumn{13}{|l|}{1 day } \\
\hline $4^{\circ} \mathrm{C}$ & 1.10 & 6.2 & 4.7 & 2.7 & 3.0 & 1.0 & & & & & & \\
\hline room temperature $\left(25^{\circ} \mathrm{C}\right)$ & 1.05 & 6.4 & 4.4 & 2.8 & 2.5 & 1.0 & & & & & & \\
\hline $\begin{array}{l}\text { Na azide }(1 \mathrm{mg} / \mathrm{ml}) \\
\text { at room temperature }\end{array}$ & 1.05 & 6.5 & 4.4 & 2.7 & 2.9 & 0.7 & & & & & & \\
\hline \multicolumn{13}{|l|}{2 days } \\
\hline $4^{\circ} \mathrm{C}$ & 1.10 & 6.6 & 4.9 & 3.0 & 2.9 & 0.9 & & & & & & \\
\hline room temperature $\left(25^{\circ} \mathrm{C}\right)$ & 0.8 & 6.6 & 4.4 & 1.2 & 1.2 & 0.8 & & & & & & \\
\hline $\begin{array}{l}\mathrm{Na} \text { azide }(1 \mathrm{mg} / \mathrm{ml}) \\
\text { at room temperature }\end{array}$ & 1.05 & 6.6 & 4.9 & 2.8 & 2.8 & 1.1 & & & & & & \\
\hline 1 month frozen & & & & & & & 3.9 & 5.0 & 5.2 & & & \\
\hline 1 year frozen & & & & & & & & & & 2.3 & 1.3 & 2.7 \\
\hline
\end{tabular}

Data are actual assay values $(\mathrm{ng} / \mathrm{ml})$ at $1: 20-1: 40$ dilutions. Samples were frozen after storage at $4^{\circ} \mathrm{C}$ or room temperature.

a Bacteriuria

Proteinuria

Table 3. Plasma glucose, plasma or serum IRI and CPR values (mean \pm SD) in normal and diabetic subjects during $50 \mathrm{~g}$ oral glucose tolerance test

\begin{tabular}{|c|c|c|c|c|c|c|c|c|}
\hline & \multirow{3}{*}{$\begin{array}{l}\text { Normal } \\
\text { subjects }\end{array}$} & \multicolumn{6}{|c|}{ Diabetic subjects } & \multirow[b]{3}{*}{ Juvenile $^{a}$} \\
\hline & & \multirow[b]{2}{*}{$\leqq 140$} & \multicolumn{2}{|l|}{$\begin{array}{l}\text { Non-obese } \\
\text { FBS (mg/dl) }\end{array}$} & \multicolumn{3}{|c|}{$\begin{array}{c}\text { Obese } \\
\text { FBS (mg/dl) }\end{array}$} & \\
\hline & & & $141-200$ & $200<$ & $\leqq 140$ & $141-200$ & $200<$ & \\
\hline \multicolumn{9}{|l|}{ Number } \\
\hline $0 \mathrm{~min}$ & $98 \pm 9$ & $110 \pm 9$ & $178 \pm 19$ & $237 \pm 35$ & $121 \pm 19$ & $165 \pm 17$ & $265 \pm 62$ & $366 \pm 150$ \\
\hline 30 & $150 \pm 22$ & $187 \pm 23$ & $271 \pm 56$ & $352 \pm 37$ & $221 \pm 54$ & $261 \pm 22$ & $372 \pm 55$ & $480 \pm 154$ \\
\hline 60 & $116 \pm 32$ & $224 \pm 36$ & $340 \pm 52$ & $398 \pm 55$ & $274 \pm 52$ & $316 \pm 39$ & $438 \pm 53$ & $516 \pm 113$ \\
\hline 岁 $\widehat{\Rightarrow} 90$ & $103 \pm 21$ & $228 \pm 21$ & $363 \pm 33$ & $413 \pm 35$ & $253 \pm 51$ & $320 \pm 67$ & $438 \pm 92$ & $531 \pm 103$ \\
\hline$\frac{0}{3} 120$ & $86 \pm 22$ & $179 \pm 22$ & $345 \pm 59$ & $406 \pm 42$ & $217 \pm 71$ & $284 \pm 58$ & $378 \pm 72$ & $485 \pm 99$ \\
\hline $\bar{\Xi} \Xi 180$ & $86 \pm 12$ & $121 \pm 35$ & $323 \pm 104$ & $331 \pm 50$ & $136 \pm 55$ & $211 \pm 69$ & $305 \pm 112$ & $411 \pm 95$ \\
\hline 0 & $9.7 \pm 6.0$ & $6.2 \pm 6.2$ & $5.0 \pm 4.2$ & $6.7 \pm 2.9$ & $9.5 \pm 6.8$ & $12.1 \pm 6.7$ & $8.3 \pm 4.0$ & $2.4 \pm 0.9$ \\
\hline 30 & $76.6 \pm 38.9$ & $17.6 \pm 14.6$ & $6.8 \pm 4.4$ & $12.3 \pm 6.5$ & $24.8 \pm 18.4$ & $24.3 \pm 11.9$ & $13.3 \pm 6.4$ & $2.4 \pm 1.7$ \\
\hline 60 & $72.2 \pm 51.7$ & $21.2 \pm 18.5$ & $9.0 \pm 6.1$ & $12.1 \pm 6.6$ & $32.5 \pm 12.5$ & $25.9 \pm 12.4$ & $13.5 \pm 9.3$ & $1.6 \pm 0.9$ \\
\hline$\widehat{\vec{\Xi}} 90$ & $43.3 \pm 22.7$ & $23.0 \pm 15.2$ & $8.7 \pm 5.3$ & $11.9 \pm 4.9$ & $33.1 \pm 10.3$ & $30.0 \pm 15.3$ & $12.9 \pm 8.3$ & $2.4 \pm 1.7$ \\
\hline$\frac{1}{D} 120$ & $20.8 \pm 11.2$ & $15.6 \pm 9.2$ & $8.8 \pm 6.8$ & $10.0 \pm 6.2$ & $28.5 \pm 14.6$ & $25.3 \pm 13.8$ & $11.0 \pm 6.3$ & $3.0 \pm 2.6$ \\
\hline 吕急 180 & $11.0 \pm 4.6$ & $7.4 \pm 5.1$ & $7.8 \pm 5.2$ & $9.9 \pm 5.4$ & $14.8 \pm 9.2$ & $14.8 \pm 6.1$ & $7.7 \pm 2.4$ & $2.0 \pm 1.7$ \\
\hline 0 & $2.45 \pm 0.96$ & $1.94 \pm 0.76$ & $2.13 \pm 0.98$ & $1.54 \pm 0.74$ & $2.58 \pm 0.86$ & $2.91 \pm 1.23$ & $2.26 \pm 0.72$ & $0.88 \pm 0.53$ \\
\hline 30 & $6.93 \pm 2.90$ & $3.26 \pm 1.11$ & $2.48 \pm 1.09$ & $2.11 \pm 0.90$ & $3.66 \pm 1.21$ & $3.96 \pm 1.41$ & $2.84 \pm 0.89$ & $1.26 \pm 0.39$ \\
\hline 60 & $7.02 \pm 2.00$ & $4.68 \pm 2.16$ & $2.90 \pm 1.04$ & $2.36 \pm 0.96$ & $4.95 \pm 1.45$ & $4.91 \pm 1.27$ & $3.01 \pm 1.19$ & $1.32 \pm 0.43$ \\
\hline$\approx 90$ & $5.84 \pm 1.65$ & $4.78 \pm 1.88$ & $3.55 \pm 1.20$ & $2.48 \pm 1.19$ & $5.67 \pm 1.22$ & $5.53 \pm 2.09$ & $3.26 \pm 1.04$ & $1.42 \pm 0.63$ \\
\hline$\not \subset \frac{E}{B} 120$ & $3.99 \pm 0.92$ & $4.42 \pm 1.70$ & $3.57 \pm 1.78$ & $2.45 \pm 0.76$ & $5.48 \pm 1.78$ & $5.49 \pm 2.41$ & $3.15 \pm 1.12$ & $1.48 \pm 0.61$ \\
\hline $8 \Xi 180$ & $2.60 \pm 0.98$ & $3.22 \pm 0.98$ & $3.65 \pm 2.05$ & $2.44 \pm 0.98$ & $4.21 \pm 1.74$ & $4.50 \pm 1.75$ & $2.70 \pm 0.71$ & $1.50 \pm 0.74$ \\
\hline
\end{tabular}

${ }^{\text {a }}$ Newly discovered, ketotic, insulin-dependent diabetic patients of young onset.

\section{Results}

\section{Evaluation of the C-Peptide Assay Method}

The mean standard curve obtained from ten assays for C-peptide immunoassay is shown in Figure 1. The percentage of radioactivity precipitated without addi- tion of standard C-peptide $\left(\mathrm{B}_{\mathrm{o}}\right)$, varied from 29 to $40 \%$ of total activity between assays, but the standard curve expressed as ratio of radioactivity precipitated (B) to $\mathbf{B}_{\mathbf{o}}$ was essentially similar. The minimal detectable concentration was about $0.2-0.3 \mathrm{ng} / \mathrm{ml}$. The best range for assay (i. e. the steepest slope of the curve) was $0.5-8 \mathrm{ng} / \mathrm{ml}$. 

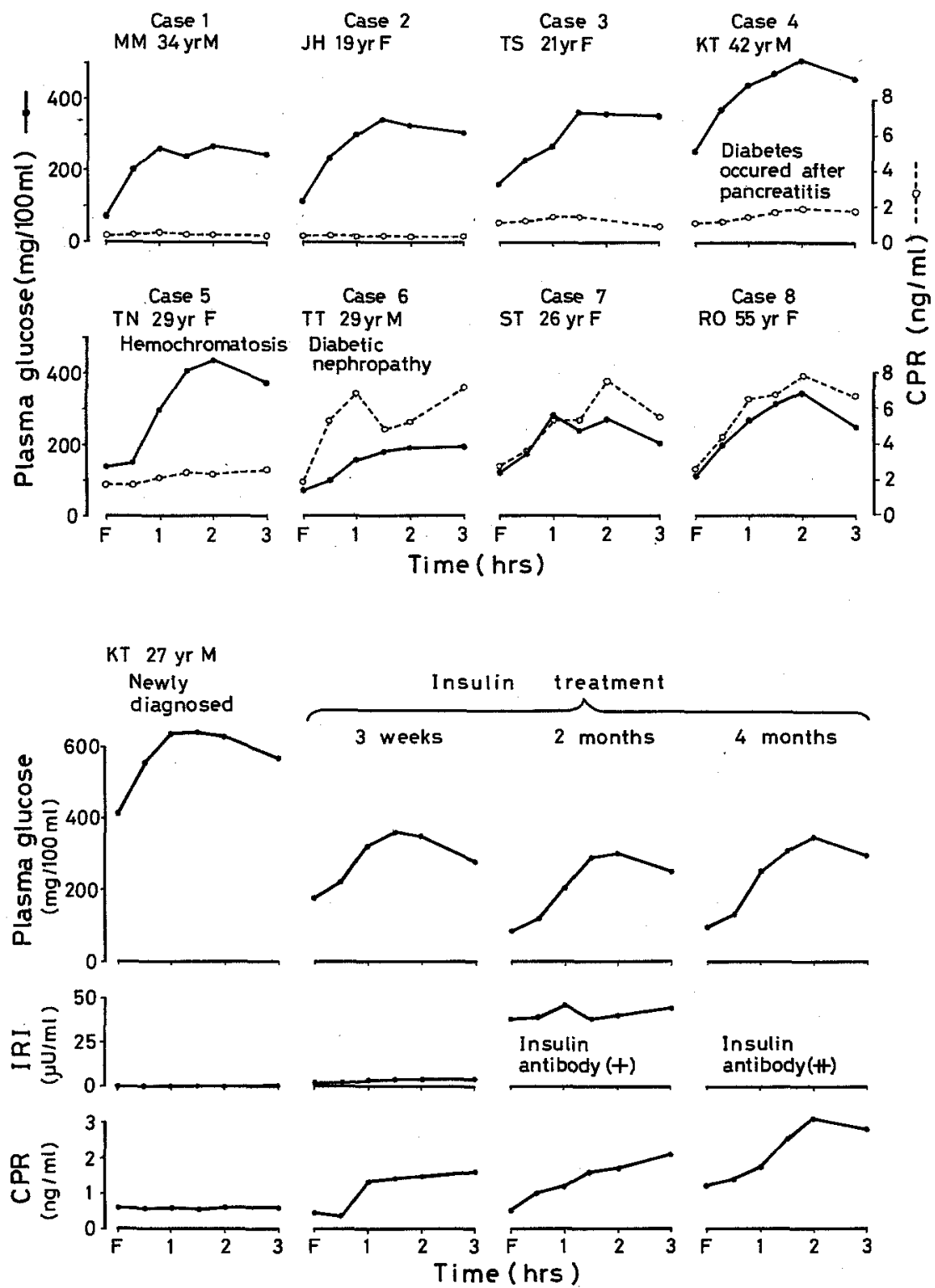

Fig. 2. Plasma glucose and CPR responses during $50 \mathrm{~g}$ oral glucose tolerance test in insulin-treated diabetic patients
Fig. 3. A course of CPR responses during $50 \mathrm{~g}$ glucose tolerance tests in a juvenile-type diabetic patient before and after insulin treatment
This assay system was unaffected by the addition of $2.5 \mathrm{mU} / \mathrm{ml}$ human monocomponent and commercial insulins (Novo and Simizu Seiyaku). Addition of dog plasma before and after intravenous xylitol injection did not decrease the precipitable radioactivity, suggesting lack of cross-reaction of this antiserum with dog C-peptide. Cross-reaction with human proinsulin was about $7 \%$ on a molar basis according to the information provided with the kit.

Dilution tests using several serum samples generally gave expected values, particularly when the assay values fell within the optimal range of the standard curve (Table $1 \mathrm{~A}$ ). Plasma and serum samples gave essentially the same values. When urine was diluted with phosphate buffer $(0.1 \mathrm{M}, \mathrm{pH} 7.4)$ containing $0.5 \%$ BSA at $1: 20$ or higher dilutions, approximately the same final values were obtained (Table $1 \mathrm{~B}$ ). At lower dilutions, urine CPR often exceeded the optimal assay range. Urine was therefore assayed initially at $1: 20$ to $1: 40$ dilutions, but if the assay value turned out to be too low, it was reassayed at 1:10 dilution.

Recovery tests were performed by the addition of known amounts of standard human C-peptide to serum or urine diluted at $1: 16$ or higher. The ratio (mean $\pm \mathrm{SD}$ ) of the difference between actual assay values, with and without additions, to the known amount of standard C-peptide added was $1.01 \pm 0.18$ for serum, and $1.01 \pm 0.21$ for diluted urine samples. 

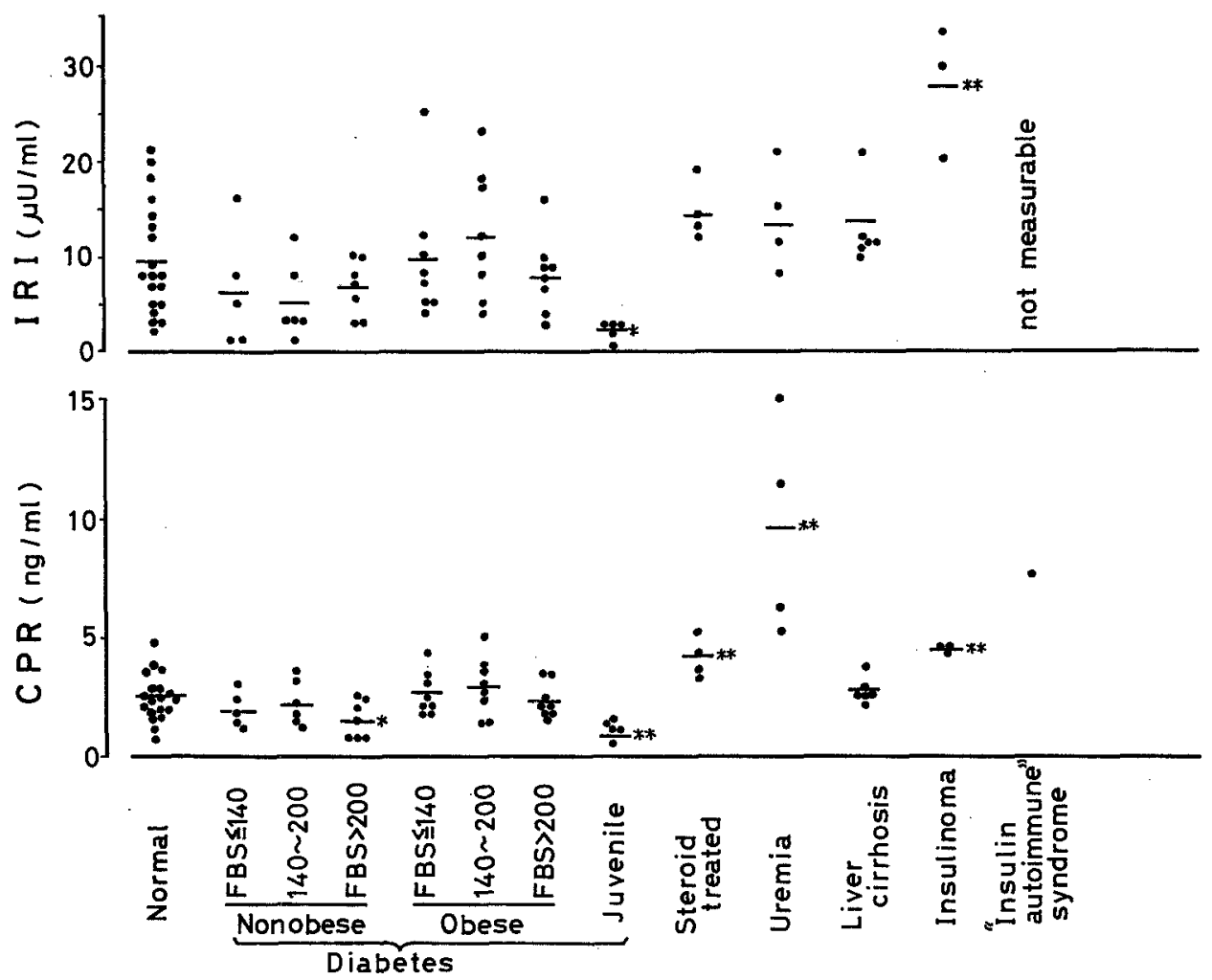

Fig. 4. Fasting plasma or serum CPR and IRI values in normal subjects and in various disease states. The mean of cach group is shown by a horizontal bar. Asterisks are attached when the mean values are significantly different from the normal group $\left({ }^{*}\right.$ and ${ }^{* *}$ imply $p<0.05$ and $p$ $<0.01$, respectively)

\section{Effect of Storage of Urine Samples}

Each of several fresh urine samples was divided into 4 aliquots; they were either stored at room temperature $\left(25^{\circ} \mathrm{C}\right)$, at $4^{\circ} \mathrm{C}$, frozen at $-20^{\circ} \mathrm{C}$, or supplemented with $\mathrm{Na}$ azide $(1 \mathrm{mg} / \mathrm{ml})$. All aliquots were assayed after storage for varying intervals. Aliquots from the same urine gave essentially the same CPR values, except when being left at room temperature (Table 2). CPR did not decrease during storage of normal urine at room temperature for 1-2 days, but is decreased in samples contaminated with bacteria. In view of these results, collection of urine and its subsequent storage were performed as mentioned previously.

Blood C-Peptide Immunoreactivity during $50 \mathrm{~g}$ Glucose Tolerance Test in Normal and Diabetic Subjects (Table 3)

Changes in serum or plasma CPR as well as immunoreactive insulin and glucose during $50 \mathrm{~g}$ oral glucose tolerance test were studied in healthy subjects and diabetic patients. In nonobese healthy people, serum CPR was $2.45 \pm 0.96 \mathrm{ng} / \mathrm{ml}$ (mean $\pm \mathrm{SD}$ )
$50 \mathrm{~g}$ glucose p.o.
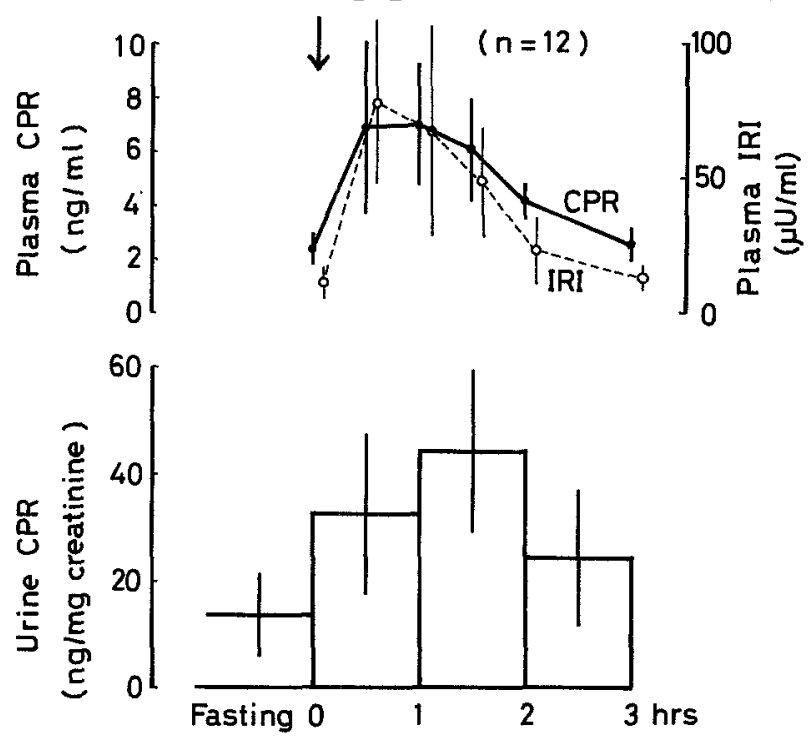

Amount of CPR excreted $(\mu \mathrm{g} / \mathrm{hr})$

$$
\begin{array}{lll}
2.43 & 2.60 & 1.15 \\
\pm 1.24 & \pm 1.57 & \pm 0.59
\end{array}
$$

Fig. 5. Plasma and urine insulin CPR during $50 \mathrm{~g}$ oral glucose tolerance test in healthy volunteers 

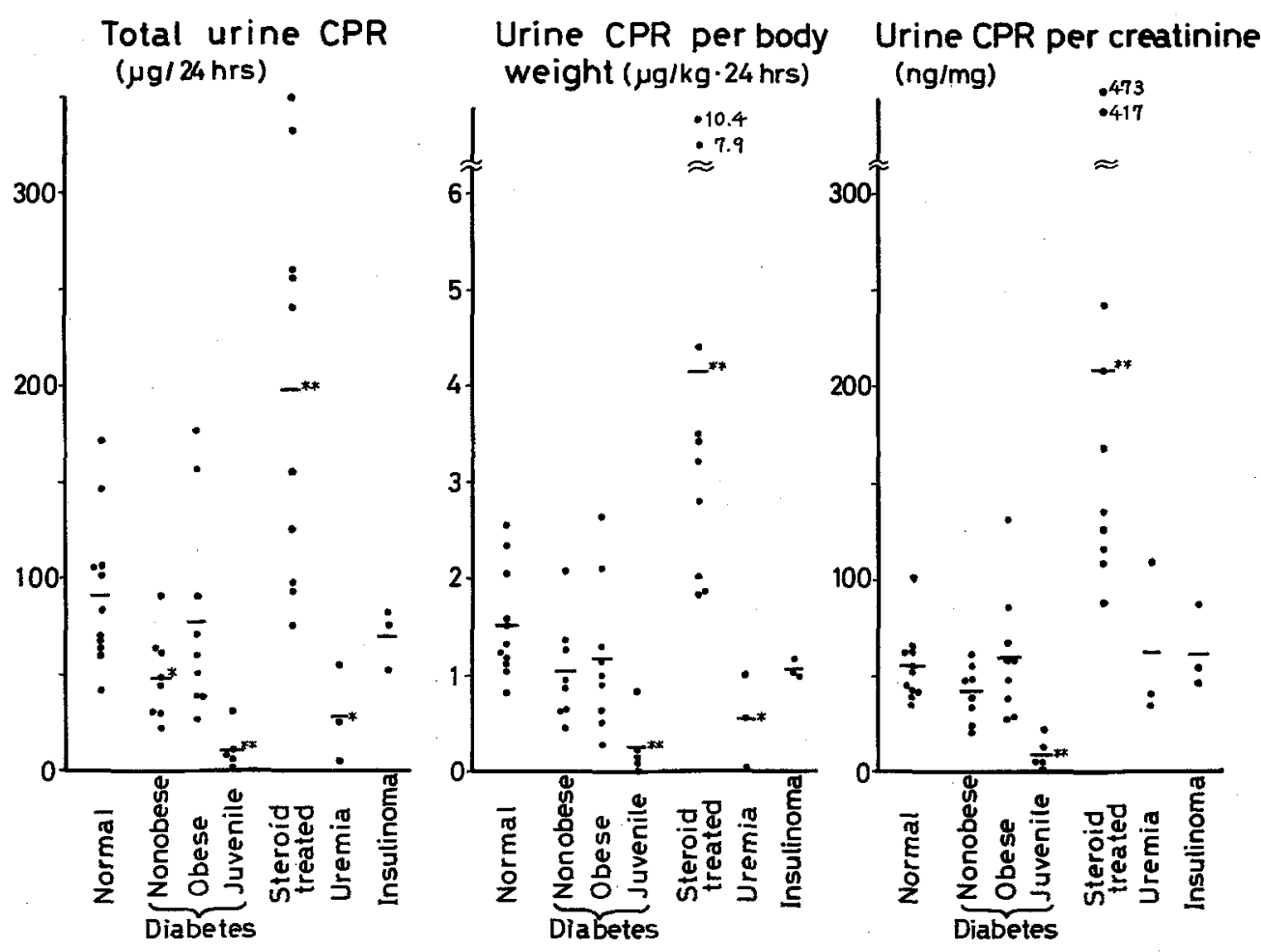

Fig. 6. Urine CPR excreted per $24 \mathrm{~h}$ in normal subjects and in various disease states. The mean of each group is shown by a horizontal bar. Asterisks are attached when the mean values are significantly different from the normal group ( ${ }^{*}$ and $* *$ imply $p<0.05$ and $p<0.01$, respectively)

fasting. It increased promptly after the glucose load, reaching a peak of $7.02 \pm 2.00 \mathrm{ng} / \mathrm{ml}$ at $60 \mathrm{~min}$ and then returned to the fasting level at $180 \mathrm{~min}$. Mean IRI changed similarly, but it reached a maximal level at $30 \mathrm{~min}$. The molar ratio of insulin to CPR was about 1:10 fasting and 1:4 after the glucose load.

Diabetic subjects were subdivided according to their fasting blood sugar and the presence or absence of obesity. Patients heavier than $110 \%$ ideal body weight were classified as obese. CPR response after glucose load tended to be delayed and diminished in groups with higher fasting blood glucose. Obese patients generally showed higher CPR values fasting and after glucose when compared with nonobese patients of similar blood sugar values. Untreated juvenile-type diabetic patients had significantly lower CPR than normal when fasting. Their CPR responses after glucose stimulation were very poor in general. In one patient CPR remained less than $0.3 \mathrm{ng} / \mathrm{ml}$, the lower limit of the assay, before and after glucose load. All of these features were similar to those of serum insulin responses. CPR responses of diabetic patients being treated with insulin varied among cases. Several examples are presented in Figure 2. Cases 1 and 2 had very low fasting CPR and virtually no rise of CPR after glucose. Cases 3, 4 and 5 had somewhat higher fasting
CPR, but the levels were subnormal and did not rise significantly after the glucose load. Cases 6,7 and 8 showed increases in CPR during $50 \mathrm{~g}$ GTT. It is possible that a part of CPR in these patients represents human proinsulin or related substance bound to insulin antibodies [3]. In an untreated juvenile-diabetic patient, serum insulin was not detectable, and CPR was also low and did not rise after glucose (Fig. 3). Three weeks after initiation of insulin treatment there was a slight response of CPR to oral glucose and 4 months later a subnormal but distinct CPR response was noted during GTT. In this patient, insulin could not be assayed after 2 months due to development of insulin antibody, but CPR assay suggested a partial recovery of endogenous B-cell secretion.

\section{Fasting Blood CPR Values in Patients with Various Diseases}

Figure 4 illustrates CPR values measured in normal subjects and in several different disease states. Fasting CPR levels in diabetic patients as a whole did not differ significantly from normal, except that juvenile-type patients had lower CPR values than normal subjects. One patient, who underwent total pancreatectomy, had no detectable CPR in his blood. 
Patients who were taking prednisolone or dexamethasone for haematological disorders had significantly higher serum CPR levels than normal. Uraemic patients had disproportionately high CPR levels as compared to IRI. Fasting CPR and IRI values were high in three insulinoma patients. A patient having spontaneous hypoglycaemia with insulin "auto-antibody" (the case C. I., reported previously [11]) had a high level of serum CPR.

\section{CPR in Urine Samples}

Figure 5 shows the changes in urine and serum CPR during $50 \mathrm{~g}$ GTT in normal subjects. CPR is expressed both by total amount excreted per hour and by ratio of CPR to creatinine in each urine sample. Urine CPR excretion in relation to creatinine increased significantly following glucose administration and decreased later, roughly paralleling the changes in serum CPR. Rough estimation of CPR clearance during $50 \mathrm{~g}$ GTT was in the range of $3-11 \mathrm{ml} / \mathrm{min}$.

The amounts of CPR in 24-h urine and their ratio to creatinine in several disease states are shown in Figure 6. CPR was expressed as the total amount and the amount excreted per $\mathrm{kg}$ body weight and the ratio to urine creatinine. CPR was not detected in urine from a patient who was totally pancreatectomized, nor in a urine sample collected during ketoacidosis from a juvenile diabetic patient. Daily excretion of CPR was normal or somewhat lower in adult-type diabetic patients and significantly low in juvenile-type patients. Urine CPR was markedly increased in patients on corticosteroid treatment. Uraemic patients excreted lower CPR per body weight than normal, but the ratio of urine CPR to creatinine was not decreased. Urine CPR was not increased in 3 insulinoma patients.

\section{Discussion}

Our results seem to indicate that this radioimmunoassay method using synthetic human C-peptide can measure CPR in human blood and urine samples adequately. This assay system showed no cross-reaction with human and other insulin preparations or with dog serum. The absence of any CPR in serum and urine of a totally depancreatized patient also suggests that this assay system really deals with the endocrine pancreatic function. However, the assay system cross-reacts with human proinsulin to some extent.

The changes in blood CPR were nearly parallel to those in IRI, except that changes in CPR were somewhat slower than those in IRI. This is compatible with the theory that C-peptide is secreted from B-cells simultaneously with insulin [12]. Fasting CPR values obtained by the present method were somewhat higher than the corresponding values reported so far. In contrast to our normal values $(2.45 \pm 0.96 \mathrm{ng} / \mathrm{ml})$, previous authors $[5,7,13]$ reported $0.88-1.3 \mathrm{ng} / \mathrm{ml}$ as mean normal CPR levels. The difference between the values of Block et al. [13] and Heding et al. [5] and ours may be partly ascribed to the different assay systems using natural and synthetic human C-peptides, but Kaneko et al. [7] used the same synthetic preparation. It is noted that Horwitz et al. [14], using a synthetic C-peptide assay system, reported 3.5-3.6 $\mathrm{ng} / \mathrm{ml}$ as mean fasting CPR values. As the synthetic human C-peptide used in this assay contains 4 more amino acids than natural $\mathrm{C}$-peptide, the difference of about $20 \%$ may be produced simply by this difference in molecular weight, if the data are expressed on a weight basis. Difference in reactivity of the antiserum with natural and synthetic C-peptides could result in differing assay values, but in vitro insulin and CPR release from a cultured human insulinoma occurred nearly in 1:1 molar ratio as measured by the same assay system [15]. In agreement with Horwitz et al. [14] and Heding and Rasmussen [16], the molar ratio of CPR to insulin in blood was greater than unity, the ratio being 4-10:1. The higher level of CPR in blood and its slower peak after stimulation are most probably due to slower metabolic clearance of CPR than insulin as suggested by Horwitz et al. [17] and Munemura [18]. Our own data also show that the half life of endogenous CPR is about twice as long as that of insulin. CPR/IRI ratio is higher fasting than after stimulation. The relatively lower blood CPR/IRI ratio in our patients with insulinomas may imply that their fasting B-cell secretion was more active than normal.

Despite the higher molar concentration of CPR than insulin, the similarity of blood insulin and CPR response patterns in normal and diabetic subjects seems to indicate that assay of CPR in blood can be a substitute for insulin assay. It is particularly useful when the radioimmunoassay of insulin cannot be performed because of the presence of insulin antibody. By this method, insulin-treated diabetic patients were shown to have differences in the secretory ability of their endocrine pancreas. The CPR assay showed that B-cell function in a juvenile-onset diabetic patient, without any rise of insulin initially, recovered to some extent after successful insulin treatment. This is similar to the observation by Block et al. [13, 19].

In accordance with the study by Kaneko et al. [20], a large amount of CPR is excreted in urine. About $13-20 \%$ of total CPR secreted per day is estimated to appear in urine, assuming that 20-30 units of insulin is secreted daily [21], and C-peptide is secreted equimolarly with insulin. Urine CPR increased after a glucose load roughly paralleling the changes in blood CPR. In 
uraemia urine CPR was low and the fasting blood CPR was high in comparison with IRI. Katz et al. [22] reported that the kidney is the principal site of C-peptide degradation in rats. Insulin is partly degraded by the kidney, but a large part is metabolized in the liver and other extrarenal tissues [23]. The greater dependence of CPR metabolism on the kidney may explain the more marked elevation of blood CPR than insulin in uraemia. It was rather unexpected to find that $24 \mathrm{~h}$ urine CPR from insulinoma patients was normal on repeated testing. Insulinoma patients presumably secrete inappropriately greater insulin than is expected from their subnormal blood sugar, but may not secrete much more insulin than normal. Except for uraemia and insulinoma, daily excretion of urine CPR was generally well correlated with blood CPR in various disease states. These data suggest that urine CPR can be used as a rough measure of endocrine function of the pancreas. The advantage of using urine as test samples is that urine is obtained more easily than blood, and the collection of a sample over a certain length of time (such as $24 \mathrm{~h}$ ) is possible, thereby permitting an estimation of overall total CPR response during this time span.

Acknowledgements. We thank Daiichi Radioisotope Laboratories for the generous supply of human Cpeptide assay kit. Human monocomponent insulin was donated by Dr. Schlichtkrull, Novo Insulin Laboratory, Copenhagen. The technical assistance of Miss Toshiko Kawanago is appreciated.

\section{References}

1. Steiner, D. F., Oyer, P. E.: The biosynthesis of insulin and probable precursor of insulin by a human islet cell adenoma. Proc. nat. Acad. Sci. (Wash.) 57, 473-480 (1967)

2. Steiner, D. F., Clark, J. L., Nolan, C., Rubenstein, A. H., Margoliash, E., Aten, B., Oyer, P. E.: Proinsulin and the biosynthesis of insulin. Recent Progr. Hormone Res. 25, 207-282 (1969)

3. Rubenstein, A. H., Block, M. B., Starr, J., Melani, F., Steiner, D. F.: Proinsulin and C-peptide in blood. Diabetes 21 (Suppl. 2), 661-672 (1972)

4. Melani, F., Rubenstein, A. H., Oyer, P. E., Steiner, D. F.: Identification of proinsulin and C-peptide in human serum by a specific immunoassay. Proc. nat. Acad. Sci. (Wash.) 67, 148-155 (1970)

5. Heding, L. G., Larsen, U. D., Markussen, J., Jørgensen, K. H., Hallund, O.: Radioimmunoassays for human, pork and ox Cpeptides and related substances. Horm. Metab. Res. 5 (Suppl.), $40-44(1974)$

6. Yanaihara, N., Hashimoto, T., Yanaihara, C., Sakagami, M.: Synthesis of human connecting peptide derivatives and their immunological properties. Biochem. biophys. Res. Commun. 59, 1124-1130(1974)
7. Kaneko, T., Oka, H., Munemura, M., Oda., Yamashita, K., Suzuki, S., Yanaihara, N., Hashimoto, T., Yanaihara, C.: Radioimmunoassay of human proinsulin, C-peptide using synthetic human connecting peptide. Endocr. jap. 21, 141-145 (1974)

8. Kanazawa, Y., Kuzuya, T., Ide, T., Kosaka, K.: Plasma insulin responses to glucose in femoral, hepatic, and pancreatic veins in dogs. Amer. J. Physiol. 211, 442-448 (1966)

9. Technicon Autoanalyzer II, clinical method No. 02, March 1972

10. Bosnes, R. W., Taussky, H. H.: On the colorimetric determination of creatinine by the Jaffe reaction. J. biol. Chem. 158, 581-591 (1945)

11. Kawazu, S., Kanazawa, Y., Kajinuma, H., Miki, E., Kuzuya, T., Kosaka, K.: Demonstration of anti-"a-component" antibody A possible means to differentiate patients with auto-antibodies to endogenous insulin from insulin-treated patients. Diabetologia 11, 169-173 (1975)

12. Rubenstein, A. H., Clark, J. L., Melani, F., Steiner, D. F.: Secretion of proinsulin C-peptide by pancreatic B-cells and its circulation in blood. Nature (Lond.) 224, 697-699 (1969)

13. Block, M. B., Mako, M. E., Steiner, D. F., Rubenstein, A. H.: Circulating C-peptide immunoreactivity. Studies in normals and diabetic patients. Diabetes 21, 1013-1026 (1972)

14. Horwitz, D. L., Starr, J. I., Mako, M. E., Blackard, W. G., Rubenstein, A. H.: Proinsulin, insulin and C-peptide concentrations in human portal and peripheral blood. $\mathbf{J}$, clin. Invest. 55, 1278-1283 (1975)

15. Kanazawa, Y., Kawazu, S., Kajinuma, H., Kosaka, K.: Secretion of insulin and C-peptide from the monolayer culture of an insulinoma (in Japanese). J. Japan Diabetic Society 18, 716 (1975)

16. Heding, L. G., Rasmussen, S. M.: Human C-peptide in normal and diabetic subjects. Diabetologia 11, 201-206 (1975)

17. Horwitz, D. L., Starr, J. I., Rubenstein, A. H., Steiner, D. F.: Serum connecting peptide - An indicator of beta cell secretory function. Diabetes 22 (Suppl. 1), 298 (1973)

18. Munemura, M., Kaneko, T., Oka, H., Yamashita, K., Suzuki, S., Oda, T., Yanaihara, N., Yanaihara, C.: Disappearance from blood of synthetic human C-peptide (in Japanese). Folia endocr. jap. 50 , 1410 (1974)

19. Block, M. B., Rosenfield, R. L., Mako, M. E., Steiner, D. F., Rubenstein, A. H.: Sequential changes in beta-cell function in insulin treated diabetic patients assessed by C-peptide immunoreactivity. New Engl. J. Med. 288, 1144-1148 (1973)

20. Kaneko, T., Munemura, M., Oka, H., Oda, T., Suzuki, H., Yasuda, H., Yanaihara, N., Nakagawa, S., Makabe, K.: Demonstration of $\mathrm{C}$-peptide immunoreactivity in various body fluids and clinical evaluation of the determination of urinary C-peptide immunoreactivity. Endocr. jap. 22, 207-212 (1975)

21. McCullagh, E., P., Cook, J. R., Shirey, E. K.; Diabetes following total pancreatectomy. Diabetes 7, 298-307 (1958)

22. Katz, A. I., Rubenstein, A. H.: Metabolism of proinsulin, insulin and C-peptide in the rat. J. clin. Invest. 52, 1113-1121 (1973)

23. Elgee, N. J., Williams, R. H., Lee, N. D.: Distribution and degradation studies with insulin- $\mathrm{I}^{131}$. J. clin. Invest. 33, 1252-1260 (1954)

Received: January 9, 1976, and in revised form: July 5, 1976

Dr. T. Kuzuya

Jichi Medical School

Minamikawachi-Machi

Tochigi-Ken

Japan 329-04 